\title{
Identification of bacterial pathogens in cultured fish with a custom peptide database constructed by matrix-assisted laser desorption/ionization time-of- flight mass spectrometry (MALDI-TOF MS)
}

Patharapol Piamsomboon

Chulalongkorn University https://orcid.org/0000-0002-6446-6884

Janthima Jaresitthikunchai

National Center for Genetic Engineering and Biotechnology

Tran Quang Hung

Jihoceska Univerzita v Ceskych Budejovicich

Sittiruk Roytrakul

National Center for Genetic Engineering and Biotechnology

Janenuj Wongtavatchai ( $\square$ janenuj.w@chula.ac.th )

Research article

Keywords: Mass spectrometry, Proteomic, Fish disease, Biotyper

Posted Date: January 8th, 2020

DOI: https://doi.org/10.21203/rs.2.15702/v2

License: (c) (i) This work is licensed under a Creative Commons Attribution 4.0 International License.

Read Full License 


\section{Abstract}

Background: The majority of infectious diseases of cultured fish is caused by bacteria. Rapid identification of bacterial pathogens is necessary for immediate management. The present study developed a matrix-assisted laser desorption/ionization time-of-flight mass spectrometry (MALDI-TOF MS) for rapid identification of fish bacterial pathogens. Streptococcus agalactiae, Streptococcus iniae, Aeromonas hydrophila, Aeromonas veronii, and Edwardsiella tarda obtained from diseased fish were used as representative bacterial pathogens in this study. Bacterial peptides were extracted to create a Main Spectra Profile (MSP), and the MSPs of each bacterial species was added into the MALDI Biotyper database. Fifteen additional isolates of each bacterial species were tested to validate the utilized technique. Results: The MSPs of all field isolates were clearly distinguishable, and the MSPs of the same species were clustered together. However, the species identification when matched with the public MALDI Biotyper library (Bruker MALDI Biotyper) showed unreliable results. Accurate identification was only obtained when using the custom-made database, giving a $100 \%$ matching result with the reference method. Conclusion: This study demonstrates an alternative technique for effective identification of fish bacterial pathogens. Further applications require a broad, well-established database to accommodate prudent identification of many fish bacterial pathogens by MALDI-TOF MS.

\section{Background}

Bacterial pathogens are a major etiology of infectious diseases of cultured fish [1]. Among those bacteria, Streptococcus spp., Aeromonas spp., and Edwardsiella spp., are commonly found in several important aquaculture species, such as the Asian catfish Clarias batrachus [2], barramundi Lates calcarifer [3], and Nile tilapia Oreochromis niloticus [4]. In many cases of bacterial infection, clinical signs and lesions are not obviously apparent and may mislead the diagnosis. Therefore, identification of disease-causing bacterial species is necessary in order to carry out proper disease management.

Conventional microbiology techniques, including morphological, physiological and biochemical tests, and molecular techniques based on 16S rDNA sequencing, are the gold standard for bacterial species identification [5]. However, these techniques require a substantial amount of time and expensive reagents [6]. In recent developments of mass spectrometry (MS), matrix-assisted laser desorption/ionization timeof-flight mass spectrometry (MALDI-TOF MS) has been implemented in human and veterinary medicine as an alternative diagnostic tool with increasing popularity due to its quickness, simplicity, costeffectiveness, and strong discriminating power $[7,8]$. The MALDI-TOF MS detects mass signals from bacterial proteins or peptides and determines their unique mass spectra or peptide mass fingerprints (PMFs). The obtained PMFs are then compared with reference bacterial strains in the public proteomics/genomics databases, or in a dedicated mass spectra library (library based approach) [9]. These mass spectra libraries are able to differentiate the bacteria to their genus, species or sub-group levels subject to sufficient pre-existing reference strains in the database [10]. 
The MALDI-TOF MS approach has been adopted as a routine diagnostic tool for human medicine [11] and has also been widely evaluated for its ability to differentiate bacterial species of veterinary and public health importance. For example, S. equi at the subspecies level [8], Streptococcus species isolated from diseased pigs [12], pathogenic Gram-negative bacteria in seafood [13] and Aeromonas species found in a drinking water system [14] have been assessed. In fish, MALDI-TOF was evaluated for the rapid identification of Gram-positive bacterial pathogens, including S. agalactiae, Lactococcus garvieae, S. iniae, and $S$. dysgalactiae isolated from Nile tilapia [15] and $S$. iniae isolated from the olive flounder Paralichthys olivaceus [16]. These studies found that the public database, the Bruker MALDI Biotyper library, was insufficient for identifying bacterial species isolated from fish with MALDI-TOF MS.

Therefore, the present study aims to develop a custom Main Spectra Profile (MSP) database and validate the method using MALDI-TOF MS for a rapid and accurate identification of $S$. agalactiae, S. iniae, A. hydrophila, A. veronii and E. tarda isolated from economically important fish species.

\section{Results}

\section{MALDI-TOF MS for bacterial species differentiation}

The high reliability of the MALDI-TOF MS was indicated by the obtained $100 \%$ recognition capabilities and by the cross-validation values of $87.8 \%, 97.1 \%, 100 \%, 100 \%$, and $100 \%$ for $S$. agalactiae, $S$. iniae. A. hydrophila, A. veronii, and $E$. tarda, respectively. The five bacterial species showed distinguishing spectral peaks ranging between 2,000-15,000 Da (Fig. 1). The 3D-PCA scatterplot presented clearly distinguishable clusters, each cluster presented in the 3D-PCA scatterplot (Fig. 2A) indicates MSPs or distinctive peptide fingerprint of the bacterial species. Bacterial isolates of the same species were grouped within the same clade of MSP dendrogram (Fig. 2B).

\section{Bacterial identification with MALDI Biotyper}

The 75 tested isolates, when blasted with the reference strains available in the Bruker database, gave noreliable identification for 23 isolates (log score 1.432-1.669), probable genus-level identification for 42 isolates (log score 1.707-1.998), and secure genus-level identification for 10 isolates (log score 2.0182.254). No species-level identification was obtained, particularly for $S$. iniae since it is not available in the Bruker database (Table 2). Differently, all 75 tested bacterial isolates yielded accurate genus-level identification with a custom MSP database, 66 isolates were identified highly probable species-level identification (log score 2.301-3.001), and 9 isolates were identified a probable species-level identification (log score 2.115-2.264). Repeatability of the method was considered with $\leq 10 \%$ deviations of log scores (Table 3). For specificity, a custom MSP database provided 100\% match with 16 s rDNA sequencing, while the Bruker database yielded matching result of $42.67 \%$ (32 out of 75 isolates).

\section{Discussion}


An accurate and repeatable method for identification of the important bacterial pathogens of aquaculture species was established in this study. This method can be performed in a relatively short time compared to conventional microbiological methods. However, the present study found that reliable identification of bacterial species was only obtained when a custom MSP database was constructed since the reference database does not always accommodate the tested pathogens. Our study shows that identification was significantly improved when a custom MSP database was applied. All 75 isolates were secure at a genuslevel identification and up to $88 \%$ (66 out of 75 isolates) were identified a highly probable species level when the identification was made on a custom MSP database. The public database may predominantly contain bacterial species that are only significant to humans but not species of veterinary importance, particularly from aquatic species [17]. The failure in species identification from the Bruker database may also result from inconsistent peptide profiles due to the use of different sample preparation protocols. The extraction method usually involves the use of organic acid to extract small-sized protein molecules, such as ribosomal proteins, cold shock proteins, and nucleic-acid binding proteins [18]. The different percentage of acid used in other studies [50\% ACN and $2.5 \% \operatorname{TFA}][16,19,20]$ may alter the pattern of those extracted proteins. Nevertheless, the ability to tailor a database expands the application of MALDI Biotyper as an identification tool for bacterial species specific to a host or location, and at below specieslevels, such as sub-species, strain, or serotype [21, 22].

The 3D-PCA scatterplot and MSP dendrogram generated from the MSPs can also be used for grouping or discriminating the type of organisms. The analyzed peptides are mainly ribosomal peptide molecules which uniquely present in the organisms [23]. In the present study, we provide an example of a MSP dendrogram created by the Biotyper software, by grouping the bacteria based on their phenotypic traits instead of their genetic traits (Fig. 2B). The software allows us to insert additional MSPs of other bacterial strains available in the reference database. Interestingly, the ATCC strains from the reference database are located in a different clade from our field strains. This may explain the failure of species identification described previously. Genotyping is usually based on phylogenetic analysis of a highly conserved region of the ribosomal RNA of the bacteria and this conservative feature may limit classification of the bacteria. Several studies have used MALDI-TOF MS as a discriminatory tool for typing bacterial pathogens $[17,24,25]$ and have found that genotypic and phenotypic traits do not always concur [26]. Thus, MALDI-TOF MS can be used as an additional method for bacterial taxonomic classification, which may benefit further research, such as epidemiology, identification of protein biomarkers, and virulence studies. For example, MALDI-TOF MS has been used to distinguish antimicrobial resistant Enterobacteriaceae [27], identify Burkholderia pseudomallei mutants [18], and Carbapenem-resistant Klebsiella pneumoniae [28].

\section{Conclusions}

To our knowledge, the present study is the first to describe a MSP database for both Gram-positive (Streptococcus) and Gram-negative (Aeromonas and Edwardsiella) bacterial pathogens of cultured fish. This method could establish species-level identifications, even when the sources of those bacteria are from different geographical locations or host species. However, this specificity can be obtained only when 
a custom MALDI Biotyper database is constructed with a standard sample preparation protocol. For the most reliable results, we suggest that the database of each user should contain a custom MSP of the active local pathogenic strains.

\section{Methods}

\section{Bacterial samples}

All bacterial isolates were obtained from clinical cases that were submitted for disease diagnosis at the Faculty of Veterinary Science, Chulalongkorn University, Thailand. Bacteriology was conducted by the methods described previously [4]. Diseased fish were dissected dorsoventrally with a sterile blade to expose the kidney. Bacterial isolation was then performed using a kidney swab onto Columbia blood agar supplemented with $5 \%$ sheep blood (Oxiod, Basingstoke, UK) and incubated at $28^{\circ} \mathrm{C}$ for 24 hours. A single colony of the pure (homogeneous colony appearance) bacterial culture on an agar plate was selected for species confirmation by conventional microbiology methods, including Gram staining, catalase and oxidase production tests, and API identification (BioMérieus ${ }^{\circledR}$, France). Bacterial species were confirmed using PCR amplification and sequencing of the 16S rDNA [29]. All bacterial isolates were stored in a nutrient broth (NB; Oxiod) containing $10 \%$ fetal calf serum and $20 \%$ glycerol at $-80^{\circ} \mathrm{C}$ for further analysis.

\section{Sample preparation for MALDI-TOF MS}

Each bacterial isolate was revived from the stock onto Columbia blood agar and incubated at $28^{\circ} \mathrm{C}$ for 18 hours. Extraction of bacterial proteins was performed as previously described [30]. A loopful of bacterial colonies was suspended in 70\% ethanol and the suspension was centrifuged at $11,000 \mathrm{~g}$ for $2 \mathrm{~min}$. The supernatant was removed, and the bacterial pellet was resuspended and mixed thoroughly with $100 \%$ acetonitrile (ACN) containing 5\% (w/v) trifluoroacetic acid (TFA). The suspension was centrifuged and the supernatant was collected for peptide measurement using Lowry's assay at $690 \mathrm{~nm}$ absorbance [31]. The concentration of peptide was adjusted to $0.1 \mu \mathrm{g} \mathrm{L}^{-1}$ for the MALDI-TOF MS analysis.

\section{MALDI-TOF MS for database generation}

Five bacterial isolates of $S$. agalactiae, $S$. iniae, A. hydrophila, A. veronii and $E$. tarda were used as a representative for the MSP database preparation (Table 1). The peptide extraction was performed once for each bacterial isolate as described above. The protocol for database construction was referred to the previous study [32]. Peptide patterns of all isolates were identified by MALDI-TOF MS to generate a database specific to each bacterial species. The MALDI matrix solution $\left[10 \mathrm{mg} \mathrm{mL}^{-1}\right.$ sinapinic acid in $100 \%$ ACN containing 5\% (w/v) TFA] was added to each sample $\left(0.1 \mu \mathrm{g} \mathrm{LL}^{-1}\right.$ peptide) at a 1:1 (v/v) ratio. The mixed samples were spotted and air dried onto a MTP 384 ground steel target plate (Bruker Daltonics, Billerica, MA, USA) as 29 individual replicates. Mass spectra were obtained using an Ultraflex III MALDI-TOF/TOF (Bruker Daltonik, GmbH, Germany) in a linear positive mode with a mass range between 2-20 kDa, a laser frequency of $50 \mathrm{~Hz}$ and 500 laser shots. A ProteoMass Peptide \& Protein MALDI-MS 
Calibration Kit (Sigma Aldrich, MO, USA) was applied for external calibrations which consisted of human angiotensin II (m/z 1,046), P14R (m/z 1,533), human adrenocorticotropic hormone fragment 18-39 (m/z $2,465)$, bovine insulin oxidized $B$ chain $(\mathrm{m} / \mathrm{z} 3,465)$, bovine insulin $(\mathrm{m} / \mathrm{z} 5,731)$, and cytochrome $C(\mathrm{~m} / \mathrm{z}$ 12,362).

Fingerprint spectra were calibrated and analyzed by the flexAnalysis software version 3.4 to assess high levels of reproducibility. The uniformity and homogeneity of the sample group as PMF and threedimensional principal component analysis (3D-PCA)were determined by t-test/ANOVA incorporated in the ClinProTools software version 3.0 [28]. A construction of a 3D-PCA scatterplot was performed using ClinProTools software.

The custom MSP database construction was performed according to Bruker's recommendation. Twenty apparent spectra were chosen from MALDI-TOF analysis of each bacterial isolate, then a total of 100 spectra from 5 isolates of one bacterial pathogen were uploaded into MALDI Biotyper software (version 4.0) and assembled to generate a MSP database for the species using the standard method of BioTyper MSP creation. The MSP dendrogram was then created to determine the relatedness of each bacterial species based on their peptide fingerprint.

\section{Method validation}

Reliability, repeatability and specificity of the method were evaluated by testing 15 bacterial isolates per bacterial species (Table 2). The bacteria were retrieved from $-80^{\circ} \mathrm{C}$ stock and processed through bacterial protein extraction, MAILDI-TOF MS, and species identification via BioTyper software using a similar protocol described above, each extracted sample was spotted as four replicates on the MALDI plate. The MSPs of these isolates were then blasted against the Bruker database and a custom MSP database. The reliability of the method was determined based on log score values computed by Biotyper software [33]; < $1.700=$ no reliable identification (indicating inaccurate identification), $\geq 1.700-1.999=$ probable genuslevel identification, 2.000-2.229 = a secure genus-level identification and a probable species-level identification, and 2.300-3.000 = a secure genus-level identification and highly probable species-level identification. The $\leq 10 \%$ variation of log scores justified repeatability. Specificity was evaluated against the reference method, $16 \mathrm{~S}$ rDNA sequencing. Numbers of the bacterial isolate that provided similar identification as detected by the reference method indicated a degree of specificity of the MALDI-TOF application.

\section{Declarations}

\section{Acknowledgments}

We thank for the technical advice from the Agricultural Research Development Agency (Public organization), Bangkok, Thailand.

\section{Authors' contributions}


PP and JW committed study design. PP, SR and JW organized the project and agreed the objectives of the study. PP and TQH executed the sample collection. PP and JJ performed the sample treatment, method validation, and instrumental analysis. PP and JW prepared initial draft of the manuscript. SR and JW made revision and refinement of the manuscript. SR and JW applied for project's funding. All Authors read and approved the final manuscript.

\section{Funding}

This study was supported by Grants for Development of New Faculty Staff, Ratchadaphiseksomphot Endowment Fund, Chulalongkorn University.

\section{Availability of data and materials}

The datasets used and analyzed during the study are available from the corresponding author upon request.

\section{Ethics approval and consent to participate}

Not applicable.

\section{Consent for publication}

Not applicable.

\section{Competing interests}

The authors declare that they have no competing interests.

\section{Author details}

${ }^{1}$ Department of Veterinary Medicine, Faculty of Veterinary Sciences, Chulalongkorn University, Bangkok, Thailand. ${ }^{2}$ Proteomics Research Laboratory, National Center for Genetic Engineering and Biotechnology, Pathum Thani, Thailand. ${ }^{3}$ University of South Bohemia in Ceske Budejovice, Faculty of Fisheries and Protection of Waters, South Bohemian Research Center of Aquaculture and Biodiversity of Hydrocenoses, Zátiší 728/II, 38925 Vodňany, Czech Republic.

\section{References}

1. Lafferty KD, Harvell CD, Conrad JM, Friedman CS, Kent ML, Kuris AM, Powell EN, Rondeau D, Saksida SM: Infectious diseases affect marine fisheries and aquaculture economics. Annu Rev Mar Sci. 2015, 7:471-496. 
2. Sahoo P, Mukherjee S, Sahoo S: Aeromonas hydrophila versus Edwardsiella tarda: a pathoanatomical study in Clarias batrachus. J Aquacult. 1998, 6:57-66.

3. Bromage ES, Owens L: Infection of barramundi Lates calcarifer with Streptococcus iniae. effects of different routes of exposure. Dis Aquat Organ. 2002, 52(3):199-205.

4. Jantrakajorn $\mathrm{S}$, Maisak $\mathrm{H}$, Wongtavatchai $\mathrm{J}$ : Comprehensive investigation of streptococcosis outbreaks in cultured Nile tilapia, Oreochromis niloticus, and red tilapia, Oreochromis sp., of Thailand. J World Aquacult Soc. 2014, 45(4):392-402.

5. Laupland KB, Valiquette $L$ : The changing culture of the microbiology laboratory. Can $\mathrm{J}$ Infect Dis Med Microbiol. 2013, 24(3):125-128.

6. Buller NB: Bacteria from fish and other aquatic animals: a practical identification manual. UK: Cabi Publishing; 2004.

7. Angeletti S: Matrix assisted laser desorption time of flight mass spectrometry (MALDI-TOF MS) in clinical microbiology. J Microbiol Methods. 2017, 138:20-29.

8. Kudirkiene E, Welker M, Knudsen NR, Bojesen AM: Rapid and accurate identification of Streptococcus equi subspecies by MALDI-TOF MS. Syst Appl Microbiol. 2015, 38(5):315-322.

9. Popović NT, Kazazić SP, Strunjak-Perović I, Čož-Rakovac R: Differentiation of environmental aquatic bacterial isolates by MALDI-TOF MS. Environ Res. 2017, 152:7-16.

10. Benagli C, Demarta A, Caminada A, Ziegler D, Petrini O, Tonolla M: A rapid MALDI-TOF MS identification database at genospecies level for clinical and environmental Aeromonas strains. PLoS One. 2012, 7(10):e48441.

11. Faron ML, Buchan BW, Hyke J, Madisen N, Lillie JL, Granato PA, Wilson DA, Procop GW, NovakWeekley S, Marlowe E: Multicenter evaluation of the Bruker MALDI Biotyper CA system for the identification of clinical aerobic gram-negative bacterial isolates. PloS one. 2015, 10(11):e0141350.

12. Pérez-Sancho M, Vela Al, García-Seco T, González S, Domínguez L, Fernández-Garayzábal JF: Usefulness of MALDI-TOF MS as a diagnostic tool for the identification of Streptococcus species recovered from clinical specimens of pigs. PloS one. 2017, 12(1):e0170784.

13. Böhme K, Fernández-No IC, Barros-Velázquez J, Gallardo JM, Calo-Mata P, Canas B: Species differentiation of seafood spoilage and pathogenic gram-negative bacteria by MALDI-TOF mass fingerprinting. J Proteome Res. 2010, 9(6):3169-3183.

14. Donohue MJ, Best JM, Smallwood AW, Kostich M, Rodgers M, Shoemaker JA: Differentiation of Aeromonas isolated from drinking water distribution systems using matrix-assisted laser desorption/ionization-mass spectrometry. Anal Chem. 2007, 79(5):1939-1946.

15. Assis GB, Pereira FL, Zegarra AU, Tavares GC, Leal CA, Figueiredo HC: Use of MALDI-TOF mass spectrometry for the fast identification of gram-positive fish pathogens. Front Microbiol. 2017, 8:1492.

16. Kim SW, Nho SW, Im SP, Lee JS, Jung JW, Lazarte JMS, Kim J, Lee W-J, Lee J-H, Jung TS: Rapid MALDI biotyper-based identification and cluster analysis of Streptococcus iniae. J Microbiol. 2017, 55(4):260-266. 
17. Kim SW, Jang HB, Lee JS, Im SP, Lazarte JMS, Seo JP, Lee WJ, Kim JS, Jung TS: Comparison of proteome typing and serotyping of Streptococcus parauberis isolates from olive flounder (Paralichthys olivaceus). J Microbiol Methods. 2015, 118:168-172.

18. Niyompanich S, Srisanga K, Jaresitthikunchai J, Roytrakul S, Tungpradabkul S: Utilization of wholecell MALDI-TOF mass spectrometry to differentiate Burkholderia pseudomallei wild-type and constructed mutants. PloS one. 2015, 10(12):e0144128.

19. Alatoom AA, Cunningham SA, Ihde SM, Mandrekar J, Patel R: Comparison of direct colony method versus extraction method for identification of Gram-positive cocci by use of Bruker Biotyper matrixassisted laser desorption ionization-time of flight mass spectrometry. J Clin Microbiol. 2011, 49(8):2868-2873.

20. Matsuda N, Matsuda M, Notake S, Yokokawa H, Kawamura Y, Hiramatsu K, Kikuchi K: Evaluation of a simple protein extraction method for species identification of clinically relevant staphylococci by matrix-assisted laser desorption ionization-time of flight mass spectrometry. J Clin Microbiol. 2012, 50(12):3862-3866.

21. Mclean K, Palarea-Albaladejo J, Currie CG, Imrie LH, Manson ED, Fraser-Pitt D, Wright F, Alexander CJ, Pollock KG, Allison L: Rapid and robust analytical protocol for $E$. coli STEC bacteria subspecies differentiation using whole cell MALDI mass spectrometry. Talanta. 2018, 182:164-170.

22. Rothen J, Pothier JF, Foucault F, Blom J, Nanayakkara D, Li C, Ip M, Tanner M, Vogel G, Pflüger V: Subspecies typing of Streptococcus agalactiae based on ribosomal subunit protein mass variation by MALDI-TOF MS. Front Microbiol. 2019, 10:471.

23. Santos IC, Hildenbrand ZL, Schug KA: Applications of MALDI-TOF MS in environmental microbiology. Analyst. 2016, 141(10):2827-2837.

24. Carannante A, De Carolis E, Vacca P, Vella A, Vocale C, De Francesco MA, Cusini M, Del Re S, Dal Conte I, Cristaudo A: Evaluation of matrix-assisted laser desorption ionization-time of flight mass spectrometry (MALDI-TOF MS) for identification and clustering of Neisseria gonorrhoeae. BMC microbiology. 2015, 15(1):142.

25. Batah R, Loucif L, Olaitan AO, Boutefnouchet N, Allag H, Rolain J-M: Outbreak of Serratia marcescens coproducing ArmA and CTX-M-15 mediated high levels of resistance to aminoglycoside and extended-spectrum beta-lactamases, Algeria. Microbial Drug Resistance. 2015, 21(4):470-476.

26. Rim JH, Lee Y, Hong SK, Park Y, Kim M, D'Souza R, Park ES, Yong D, Lee K: Insufficient discriminatory power of matrix-assisted laser desorption ionization time-of-flight mass spectrometry dendrograms to determine the clonality of multi-drug-resistant Acinetobacter baumannii isolates from an intensive care unit. Biomed Res Int. 2015, 2015:535027.

27. Arpornsuwan T, Paveenkittiporn W, Jaresitthikunchai J, Roytrakul S: BAMP-28 Antimicrobial Peptide Against Different MALDI Biotype of Carbapenam Resistant Enterobacteriaceae. International Journal of Peptide Research and Therapeutics. 2018:1-10.

28. Meng X, Yang J, Duan J, Liu S, Huang X, Wen X, Huang X, Fu C, Li J, Dou Q: Assessing Molecular Epidemiology of Carbapenem-resistant Klebsiella pneumoniae (CR-KP) with MLST and MALDI-TOF 
in Central China. Scientific reports. 2019, 9(1):2271.

29. Weisburg WG, Barns SM, Pelletier DA, Lane DJ: 16S ribosomal DNA amplification for phylogenetic study. J Bacteriol. 1991, 173(2):697-703.

30. Jaresitthikunchai J., Phanphiriya P., S. R: MALDI-TOF Mass Spectrometric Fingerprint for Direct Identification of Bacillus, Escherichia, Staphylococcus, Enterobacter, Pseudomonas from Colonies Grown on Agar Plates In: Proceeding of The 3rd International Conference on Biochemistry and Molecular Biology 2011; 2011.

31. Lowry OH, Rosebrough NJ, Farr AL, Randall RJ: Protein measurement with the Folin phenol reagent. J Biol Chem. 1951, 193:265-275.

32. Sonthayanon $P$, Jaresitthikunchai J, Mangmee $S$, Thiangtrongjit T, Wuthiekanun $V$, Amornchai $P$, Newton P, Phetsouvanh R, Day NP, Roytrakul S: Whole cell matrix assisted laser desorption/ionization time-of-flight mass spectrometry (MALDI-TOF MS) for identification of Leptospira spp. in Thailand and Lao PDR. PLoS neglected tropical diseases. 2019, 13(4):e0007232.

33. Cherkaoui A, Hibbs J, Emonet S, Tangomo M, Girard M, Francois P, Schrenzel J: Comparison of two matrix-assisted laser desorption ionization-time of flight mass spectrometry methods with conventional phenotypic identification for routine identification of bacteria to the species level. J Clin Microbiol. 2010, 48(4):1169-1175.

\section{Tables}

Table 1 Bacterial pathogens used for the development the custom MSP database. The isolates were obtained from cultured Nile tilapia Oreochromis niloticus, red tilapia Oreochromis spp., barramundi Lates calcarifer, hybrid catfish Clarias macrocephalus $\times$ C. gariepinus, and Snakehead fish Channa striata. 


\begin{tabular}{|c|c|c|c|c|}
\hline Bacterial species & Isolate number & Year & Source & Region \\
\hline \multirow{5}{*}{ S. agalactiae } & S147-J & 2013 & Nile tilapia & Western Thailand \\
\hline & S183-J & 2015 & Red tilapia & Central Thailand \\
\hline & S187-J & 2017 & Nile tilapia & Eastern Thailand \\
\hline & S190-J & 2018 & Red tilapia & Southern Thailand \\
\hline & SV1/1-J & 2018 & Nile tilapia & Northern Vietnam \\
\hline \multirow[t]{5}{*}{ S. iniae } & NS12-J & 2007 & Red tilapia & Northeastern Thailand \\
\hline & NS70-J & 2012 & Nile tilapia & Northeastern Thailand \\
\hline & NS74-J & 2014 & Barramundi & Eastern Thailand \\
\hline & NS76-J & 2014 & Barramundi & Eastern Thailand \\
\hline & NS185-J & 2018 & Barramundi & Eastern Thailand \\
\hline \multirow[t]{5}{*}{ A. hydrophila } & A28-J & 2011 & Nile tilapia & Eastern Thailand \\
\hline & A29-J & 2011 & Hybrid catfish & Eastern Thailand \\
\hline & A49-J & 2013 & Red tilapia & Central Thailand \\
\hline & A50-J & 2015 & Nile tilapia & Eastern Thailand \\
\hline & A84-J & 2017 & Snakehead fish & Central Thailand \\
\hline \multirow[t]{5}{*}{ A. veronii } & SB1-J & 2017 & Nile tilapia & Eastern Thailand \\
\hline & SB2-J & 2017 & Nile tilapia & Eastern Thailand \\
\hline & SB3-J & 2018 & Barramundi & Eastern Thailand \\
\hline & SB4-J & 2019 & Barramundi & Eastern Thailand \\
\hline & SB7-J & 2019 & Red tilapia & Eastern Thailand \\
\hline \multirow[t]{5}{*}{ E. tarda } & Ed10-J & 2012 & Hybrid catfish & Central Thailand \\
\hline & Ed12-J & 2013 & Hybrid catfish & Central Thailand \\
\hline & Ed14-J & 2015 & Nile tilapia & Eastern Thailand \\
\hline & Ed16-J & 2016 & Nile tilapia & Eastern Thailand \\
\hline & Ed18-J & 2017 & Nile tilapia & Central Thailand \\
\hline
\end{tabular}

Table 2 Method validation of the MALDI Biotyper of five bacterial pathogens showing the matching results with the 16s rDNA sequencing, custom MSP and Bruker MSP database. The identity was calculated against NCBI database. 


\begin{tabular}{|c|c|c|c|c|c|c|c|}
\hline \multirow{3}{*}{$\begin{array}{l}\text { Isolate } \\
\text { number }\end{array}$} & \multirow[t]{3}{*}{ Source } & \multirow{2}{*}{\multicolumn{2}{|c|}{ 16S rDNA sequencing }} & \multicolumn{4}{|c|}{ MALDI-TOF } \\
\hline & & & & \multicolumn{2}{|c|}{ Custom MSP database } & \multicolumn{2}{|c|}{ Bruker MSP database } \\
\hline & & $\begin{array}{c}\text { Organism best } \\
\text { match }\end{array}$ & $\begin{array}{c}\% \\
\text { identity }\end{array}$ & $\begin{array}{c}\text { Organism best } \\
\text { match }\end{array}$ & $\begin{array}{c}\text { Log } \\
\text { score }\end{array}$ & $\begin{array}{c}\text { Organism best } \\
\text { match }\end{array}$ & $\begin{array}{c}\text { Log } \\
\text { score }\end{array}$ \\
\hline \multicolumn{8}{|c|}{ Streptococcus spp. } \\
\hline S147-J* & Nile tilapia & S. agalactiae & 100 & S. agalactiae & 2.999 & S. parauberis & 1.877 \\
\hline S183-J* & Red tilapia & S. agalactiae & 100 & S. agalactiae & 2.897 & S. parauberis & 1.665 \\
\hline S187-J* & Nile tilapia & S. agalactiae & 99 & S. agalactiae & 2.988 & S. agalactiae & 1.545 \\
\hline S190-J* & Red tilapia & S. agalactiae & 99 & S. agalactiae & 2.856 & S. agalactiae & 1.998 \\
\hline SV1/1-J* & Nile tilapia & S. agalactiae & 100 & S. agalactiae & 2.945 & S. agalactiae & 2.019 \\
\hline S71 & Red tilapia & S. agalactiae & 99 & S. agalactiae & 2.244 & S. urinalis & 1.666 \\
\hline S96 & Red tilapia & S. agalactiae & 100 & S. agalactiae & 2.377 & S. agalactiae & 1.756 \\
\hline S100 & Nile tilapia & S. agalactiae & 99 & S. agalactiae & 2.442 & S. agalactiae & 1.582 \\
\hline S101 & Nile tilapia & S. agalactiae & 99 & S. agalactiae & 2.375 & S. parauberis & 1.829 \\
\hline S102 & Nile tilapia & S. agalactiae & 98 & S. agalactiae & 2.544 & S. parauberis & 1.876 \\
\hline S183 & Red tilapia & S. agalactiae & 100 & S. agalactiae & 2.388 & S. agalactiae & 1.716 \\
\hline S184 & Red tilapia & S. agalactiae & 100 & S. agalactiae & 2.591 & S. agalactiae & 1.749 \\
\hline S191 & Red tilapia & S. agalactiae & 99 & S. agalactiae & 2.347 & S. urinalis & 1.564 \\
\hline S195 & Nile tilapia & S. agalactiae & 97 & S. agalactiae & 2.455 & S. agalactiae & 1.632 \\
\hline S198 & Nile tilapia & S. agalactiae & 99 & S. agalactiae & 2.544 & S. agalactiae & 1.908 \\
\hline NS12-J* & Red tilapia & S. iniae & 100 & S. iniae & 2.898 & S. agalactiae & 1.432 \\
\hline NS70-J* & Nile tilapia & S. iniae & 100 & S. iniae & 2.988 & S. agalactiae & 1.688 \\
\hline NS74-J* & Barramundi & S. iniae & 100 & S. iniae & 2.878 & S. parauberis & 1.987 \\
\hline NS76-J* & Barramundi & S. iniae & 99 & S. iniae & 2.999 & S. pyogenes & 1.555 \\
\hline NS185-J* & Barramundi & S. iniae & 99 & S. iniae & 2.778 & S. parauberis & 1.654 \\
\hline NS11 & Nile tilapia & S. iniae & 98 & S. iniae & 2.376 & S. agalactiae & 1.997 \\
\hline NS18 & Nile tilapia & S. iniae & 100 & S. iniae & 2.419 & S. agalactiae & 1.707 \\
\hline NS26 & Red tilapia & S. iniae & 99 & S. iniae & 2.534 & S. pyogenes & 1.728 \\
\hline NS34 & Barramundi & S. iniae & 96 & S. iniae & 2.544 & S. agalactiae & 1.886 \\
\hline NS50 & Barramundi & S. iniae & 97 & S. iniae & 2.308 & S. pyogenes & 1.679 \\
\hline NS84 & Barramundi & S. iniae & 98 & S. iniae & 2.118 & S. pyogenes & 1.679 \\
\hline NS85 & Barramundi & S. iniae & 98 & S. iniae & 2.445 & S. agalactiae & 1.864 \\
\hline NS89 & Red tilapia & S. iniae & 99 & S. iniae & 2.342 & S. agalactiae & 1.975 \\
\hline NS90 & Red tilapia & S. iniae & 100 & S. iniae & 2.221 & S. agalactiae & 1.873 \\
\hline NS91 & Nile tilapia & S. iniae & 100 & S. iniae & 2.464 & S. parauberis & 1.593 \\
\hline \multicolumn{8}{|c|}{ Aeromonas spp. } \\
\hline A28-J* & Nile tilapia & A. hydrophila & 100 & A. hydrophila & 2.978 & A. veronii & 1.495 \\
\hline A29-J* & $\begin{array}{l}\text { Hybrid } \\
\text { catfish }\end{array}$ & A. hydrophila & 100 & A. hydrophila & 2.991 & A. veronii & 1.767 \\
\hline A49-J* & Red tilapia & A. hydrophila & 100 & A. hydrophila & 2.965 & A. hydrophila & 1.869 \\
\hline A50-J* & Nile tilapia & A. hydrophila & 100 & A. hydrophila & 2.889 & A. ichthiosmia & 2.094 \\
\hline
\end{tabular}




\begin{tabular}{|c|c|c|c|c|c|c|c|}
\hline \multirow{3}{*}{$\begin{array}{l}\text { Isolate } \\
\text { number }\end{array}$} & \multirow[t]{3}{*}{ Source } & \multirow{2}{*}{\multicolumn{2}{|c|}{ 16S rDNA sequencing }} & \multicolumn{4}{|c|}{ MALDI-TOF } \\
\hline & & & & \multicolumn{2}{|c|}{ Custom MSP database } & \multicolumn{2}{|c|}{ Bruker MSP database } \\
\hline & & $\begin{array}{c}\text { Organism best } \\
\text { match }\end{array}$ & $\begin{array}{c}\% \\
\text { identity }\end{array}$ & $\begin{array}{l}\text { Organism best } \\
\text { match }\end{array}$ & $\begin{array}{l}\text { Log } \\
\text { score }\end{array}$ & $\begin{array}{l}\text { Organism best } \\
\text { match }\end{array}$ & $\begin{array}{l}\text { Log } \\
\text { score }\end{array}$ \\
\hline A84-J* & $\begin{array}{l}\text { Snakehead } \\
\text { fish }\end{array}$ & A. hydrophila & 100 & A. hydrophila & 2.945 & A. hydrophila & 1.755 \\
\hline A90 & Nile tilapia & A. hydrophila & 99 & A. hydrophila & 2.312 & A. veronii & 2.018 \\
\hline A108 & $\begin{array}{l}\text { Hybrid } \\
\text { catfish }\end{array}$ & A. hydrophila & 100 & A. hydrophila & 2.464 & A. hydrophila & 1.956 \\
\hline A109 & Red tilapia & A. hydrophila & 100 & A. hydrophila & 2.115 & A. hydrophila & 1.848 \\
\hline A110 & $\begin{array}{l}\text { Snakehead } \\
\text { fish }\end{array}$ & A. hydrophila & 98 & A. hydrophila & 2.394 & A. hydrophila & 2.181 \\
\hline A112 & $\begin{array}{l}\text { Snakehead } \\
\text { fish }\end{array}$ & A. hydrophila & 98 & A. hydrophila & 2.601 & A. hydrophila & 2.011 \\
\hline A114 & Nile tilapia & A. hydrophila & 97 & A. hydrophila & 2.451 & A. veronii & 1.995 \\
\hline A115 & Nile tilapia & A. hydrophila & 97 & A. hydrophila & 2.551 & A. ichthiosmia & 2.045 \\
\hline A120 & $\begin{array}{l}\text { Hybrid } \\
\text { catfish }\end{array}$ & A. hydrophila & 99 & A. hydrophila & 2.009 & A. veronii & 1.454 \\
\hline A126 & $\begin{array}{l}\text { Snakehead } \\
\text { fish }\end{array}$ & A. hydrophila & 100 & A. hydrophila & 2.567 & A. veronii & 1.777 \\
\hline A127 & $\begin{array}{l}\text { Snakehead } \\
\text { fish }\end{array}$ & A. hydrophila & 99 & A. hydrophila & 2.301 & A. shigelloides & 1.985 \\
\hline SB1-J* & Nile tilapia & A. veronii & 100 & A. veronii & 2.969 & A. hydrophila & 1.559 \\
\hline SB2-J* & Nile tilapia & A. veronii & 99 & A. veronii & 3.000 & A. shigelloides & 1.997 \\
\hline SB3-J* & Barramundi & A. veronii & 99 & A. veronii & 2.897 & A. veronii & 1.787 \\
\hline SB4-J* & Barramundi & A. veronii & 100 & A. veronii & 2.888 & A. veronii & 1.945 \\
\hline SB7-J* & Red tilapia & A. veronii & 98 & A. veronii & 2.899 & A. shigelloides & 1.658 \\
\hline SB5 & Nile tilapia & A. veronii & 98 & A. veronii & 2.327 & A. ichthiosmia & 2.027 \\
\hline SB6 & Nile tilapia & A. veronii & 100 & A. veronii & 2.454 & A. hydrophila & 1.787 \\
\hline SB8 & Barramundi & A. veronii & 98 & A. veronii & 2.382 & A. hydrophila & 1.844 \\
\hline SB9 & Barramundi & A. veronii & 98 & A. veronii & 2.511 & A. veronii & 1.906 \\
\hline SB10 & Barramundi & A. veronii & 97 & A. veronii & 2.377 & A. veronii & 1.733 \\
\hline SB12 & Barramundi & A. veronii & 100 & A. veronii & 2.401 & A. veronii & 1.667 \\
\hline SB13 & Barramundi & A. veronii & 99 & A. veronii & 2.359 & A. hydrophila & 1.872 \\
\hline SB14 & Barramundi & A. veronii & 97 & A. veronii & 2.228 & A. ichthiosmia & 1.560 \\
\hline SB15 & Barramundi & A. veronii & 100 & A. veronii & 2.553 & A. veronii & 1.924 \\
\hline SB17 & Barramundi & A. veronii & 100 & A. veronii & 2.198 & A. veronii & 1.855 \\
\hline \multicolumn{8}{|c|}{ Edwardsiella tarda } \\
\hline Ed10-J* & $\begin{array}{l}\text { Hybrid } \\
\text { catfish }\end{array}$ & E. tarda & 100 & E. tarda & 2.899 & E. tarda & 2.000 \\
\hline Ed12-J* & $\begin{array}{l}\text { Hybrid } \\
\text { catfish }\end{array}$ & E. tarda & 100 & E. tarda & 2.932 & E. tarda & 1.887 \\
\hline Ed14-J* & Nile tilapia & E. tarda & 99 & E. tarda & 2.984 & E. tarda & 1.666 \\
\hline Ed16-J* & Nile tilapia & E. tarda & 98 & E. tarda & 3.000 & E. hoshinae & 1.669 \\
\hline Ed18-J* & Nile tilapia & E. tarda & 100 & E. tarda & 2.999 & E. hoshinae & 1.842 \\
\hline
\end{tabular}




\begin{tabular}{|c|c|c|c|c|c|c|c|}
\hline \multirow{3}{*}{$\begin{array}{l}\text { Isolate } \\
\text { number }\end{array}$} & \multirow[t]{3}{*}{ Source } & \multirow{2}{*}{\multicolumn{2}{|c|}{ 16S rDNA sequencing }} & \multicolumn{4}{|c|}{ MALDI-TOF } \\
\hline & & & & \multicolumn{2}{|c|}{ Custom MSP database } & \multicolumn{2}{|c|}{ Bruker MSP database } \\
\hline & & $\begin{array}{l}\text { Organism best } \\
\text { match }\end{array}$ & $\begin{array}{c}\% \\
\text { identity }\end{array}$ & $\begin{array}{l}\text { Organism best } \\
\text { match }\end{array}$ & $\begin{array}{l}\text { Log } \\
\text { score }\end{array}$ & $\begin{array}{l}\text { Organism best } \\
\text { match }\end{array}$ & $\begin{array}{l}\text { Log } \\
\text { score }\end{array}$ \\
\hline Ed8 & $\begin{array}{l}\text { Hybrid } \\
\text { catfish }\end{array}$ & E. tarda & 99 & E. tarda & 2.382 & E. hoshinae & 1.584 \\
\hline Ed9 & $\begin{array}{l}\text { Hybrid } \\
\text { catfish }\end{array}$ & E. tarda & 100 & E. tarda & 2.367 & E. hoshinae & 1.624 \\
\hline Ed11 & $\begin{array}{l}\text { Hybrid } \\
\text { catfish }\end{array}$ & E. tarda & 98 & E. tarda & 2.203 & E. hoshinae & 1.782 \\
\hline Ed17 & Nile tilapia & E. tarda & 99 & E. tarda & 2.471 & E. tarda & 1.977 \\
\hline Ed20 & Nile tilapia & E. tarda & 100 & E. tarda & 2.457 & E. tarda & 1.945 \\
\hline Ed23 & $\begin{array}{l}\text { Hybrid } \\
\text { catfish }\end{array}$ & E. tarda & 98 & E. tarda & 2.457 & E. tarda & 2.254 \\
\hline Ed25 & $\begin{array}{l}\text { Hybrid } \\
\text { catfish }\end{array}$ & E. tarda & 100 & E. tarda & 2.342 & E. tarda & 1.963 \\
\hline Ed27 & Nile tilapia & E. tarda & 100 & E. tarda & 2.264 & E. tarda & 2.014 \\
\hline Ed30 & Nile tilapia & E. tarda & 100 & E. tarda & 2.445 & E. tarda & 2.002 \\
\hline Ed31 & Nile tilapia & E. tarda & 100 & E. tarda & 2.116 & E. tarda & 1.956 \\
\hline
\end{tabular}

*Isolate used for MSP database construction.

$\log$ score values: $<1.700=$ no reliable identification, $\geq 1.700-1.999=$ probable genus-level identification, 2.000-2.229 = a secure genus-level identification and a probable species-level identification, and 2.300-3.000 = a secure species-level identification and highly probable species-level identification.

Table 3 Comparison of the test results for bacterial species identification using a custom MSP database and Bruker database. 


\begin{tabular}{llcc}
\hline Pathogen & $\begin{array}{c}\text { MSP } \\
\text { database }\end{array}$ & $\begin{array}{c}\text { No. of isolate matched with 16s rDNA sequencing } \\
(\%)\end{array}$ & $\begin{array}{c}\text { Mean log score } \pm \text { SD } \\
\text { (Min - Max) }\end{array}$ \\
\hline $\begin{array}{l}\text { S. } \\
\text { agalactiae }\end{array}$ & Custom & $15 / 15(100 \%)$ & $2.599 \pm 0.26(2.244-$ \\
& Bruker & $9 / 15(60 \%)$ & $1.758 \pm 0.15(2.545-$ \\
& & $15 / 15(100 \%)$ & $2.019)$
\end{tabular}

Figures 

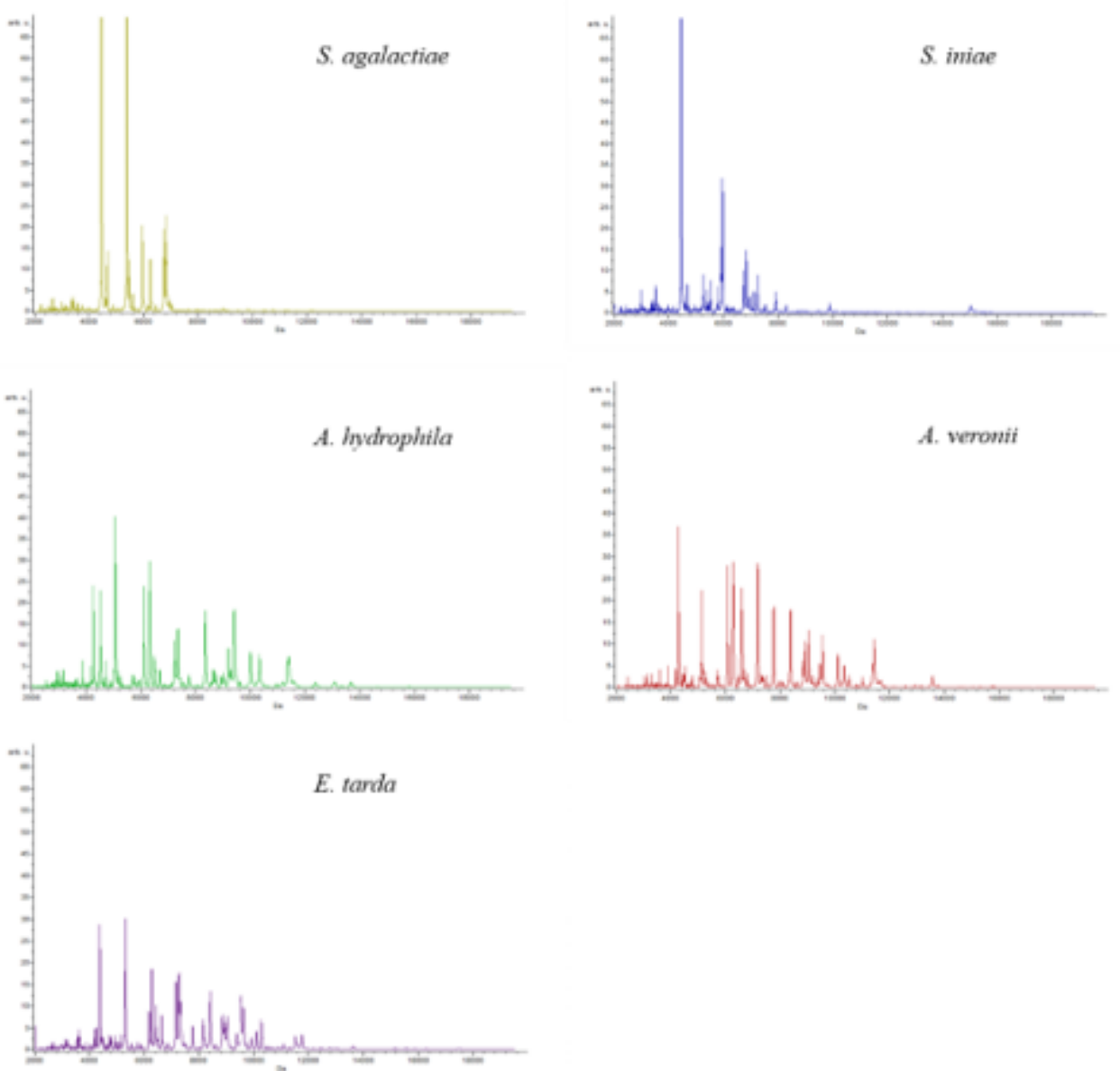

\section{Figure 1}

Mass peptide fingerprints of five bacterial pathogens (S. agalactiae, S. iniae, A. hydrophila, A. veronii and E. tarda) isolated from cultured fish. 
$\mathbf{A}$

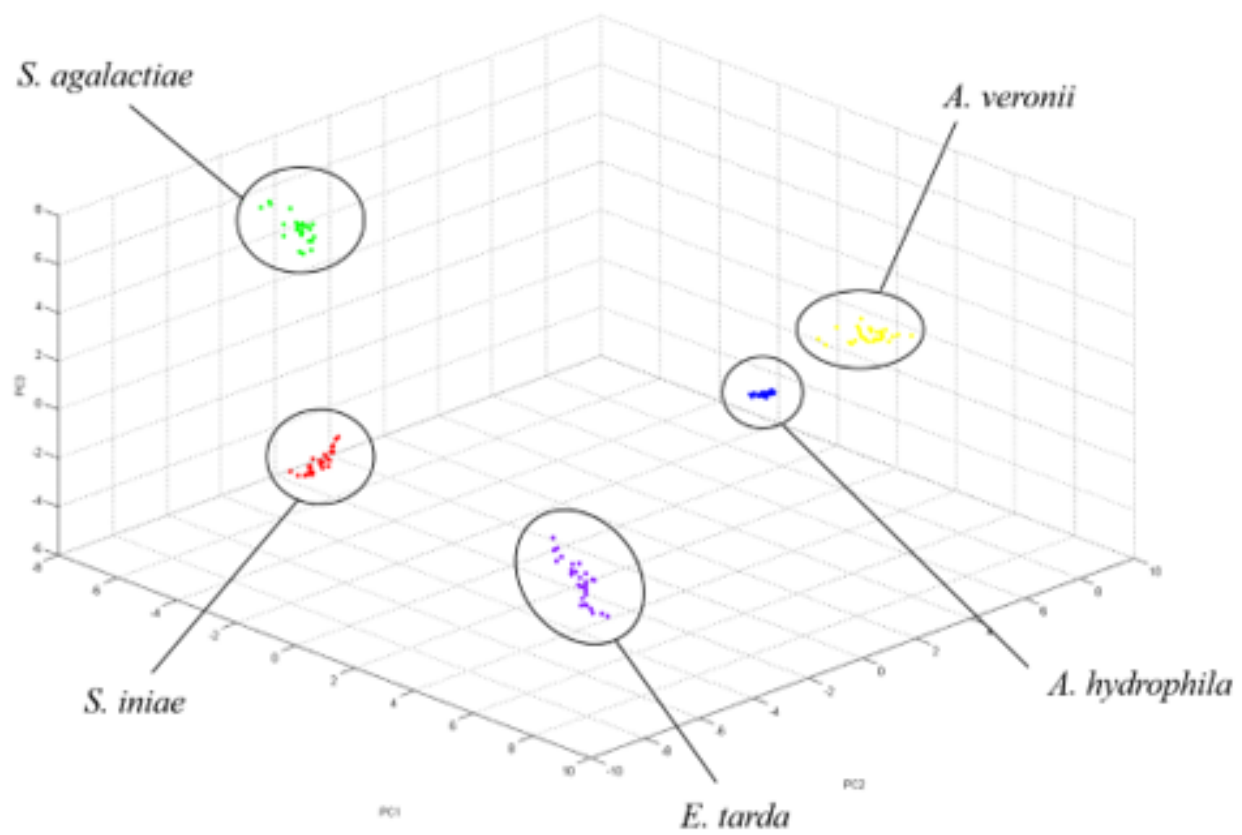

B

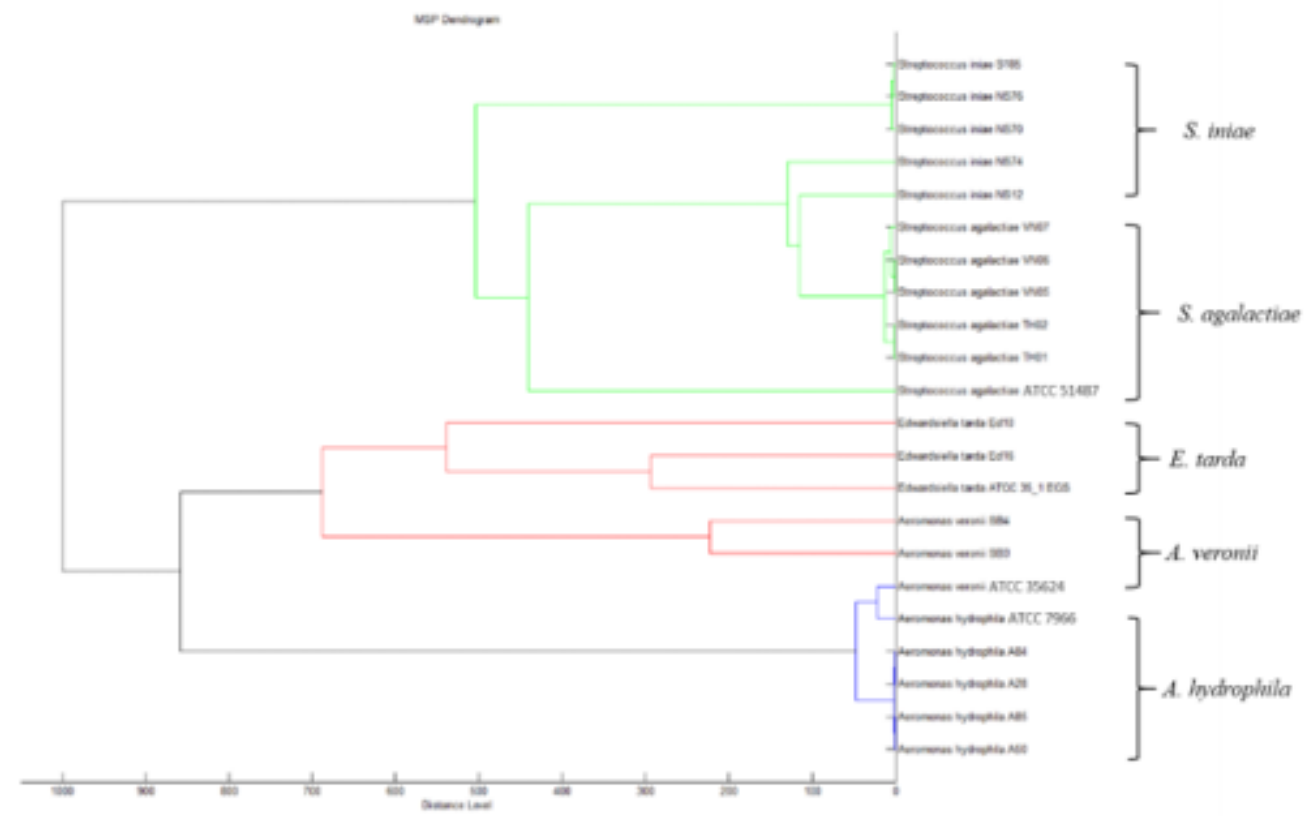

Figure 2

Cluster analysis of the five bacterial pathogens (S. agalactiae, S. iniae, A. hydrophila, A. veronii and E. tarda) isolated from cultured fish. (A) The 3D-PCA scatterplot representing clusters of each species (dashed circles) and the (B) MSP dendrogram of the representative bacterial isolates analyzed in the present study with the reference ATCC strains. 